University of Windsor

Scholarship at UWindsor

\title{
The Relationship between Management and Financial Accounting as Professions and Technologies of Practice
}

\author{
Alan J. Richardson
}

University of Windsor

Follow this and additional works at: https://scholar.uwindsor.ca/odettepub

Part of the Business Commons, Organizational Communication Commons, and the Work, Economy and Organizations Commons

\section{Recommended Citation}

Richardson, Alan J.. (2017). The Relationship between Management and Financial Accounting as Professions and Technologies of Practice. The Role of the Management Accountant - Local Variations and Global Influences (Routledge Studies in Accounting).

https://scholar.uwindsor.ca/odettepub/103

This Contribution to Book is brought to you for free and open access by the Odette School of Business at Scholarship at UWindsor. It has been accepted for inclusion in Odette School of Business Publications by an authorized administrator of Scholarship at UWindsor. For more information, please contact scholarship@uwindsor.ca. 
Goretzki \& Strauss : « The Role of the Management Accountant»

The relationship between management and financial accounting as professions and technologies of practice

Alan J. Richardson

Chapter C3 in

Lukas Goretzki (University of Innsbruck) \& Erik Strauss (University of Witten/Herdecke) (Eds.)

The Role of the Management Accounting - Local Variations and Global Influences

(Routledge Studies in Accounting) forthcoming 2017 
The relationship between management and financial accounting as professions and technologies of practice

\title{
Alan J. Richardson ${ }^{1}$
}

\begin{abstract}
This Chapter explores the suggestion to unify financial and management accounting both as professions and technologies of practice. I argue that drift in professional jurisdictions and cognitive domains encourages consolidation of the profession but there remain distinct social roles for each information technology. The challenge for the profession is to maintain the integrity of management accounting as a technology of practice in the face of renewed professional hegemony of financial accounting.
\end{abstract}

\section{Introduction}

Management accounting as a distinct profession emerged after WWI and developed a technology of practice distinct from financial accounting. In part, its emergence reflected the importance of operational efficiency in the war effort and the development of specialists in budgeting and costing (Loft, 1989; c.f. Boyns and Edwards, 1997, 2006). However, it also arose as a distinct profession because of the exclusionary practices of existing accounting associations who wished to maintain the purity of public accounting in the face of increasing numbers of salaried accountants. Recently there have been calls to unify these branches of accounting thought and professional organization but important questions are raised by these trends.

Management accounting information is needed to support financial reporting and, as financial reporting became more future-oriented and investor focused, the assumptions underlying budgeting and operational planning became input to financial accounting policies and estimates (Taipaleenmäki \& Ikäheimo, 2013; Ahmed \& Duellman, 2013). This has led to calls for the unification of financial accounting and management accounting as technologies of practice. But management accounting has expanded its areas of practice to support strategy implementation, competition on the basis of quality and social impact, and stakeholder management. If merging these technologies of practice occurred would it represent the continued dominance of the shareholder view of accounting underlying financial reporting or would a new synthesis be needed that reflected a broader set of stakeholders and issues in organizations?

Membership in management accounting associations is growing faster than membership in financial accounting associations creating potential usurpatory challenges to the hegemony of financial accounting in the market for professional credentials. Management accountants have developed a distinct identity and regard their careers as independent of financial accounting (Richardson and Jones, 2007; Weaver and Whitney, 2015). If a merger of professional associations

\footnotetext{
${ }^{1}$ I would like to acknowledge the research assistance of Andrew Leboeuf and Belinda Cancian, the support of the University of Windsor Outstanding Scholars Program, and the helpful comments of the Editors.
} 
occurred, would it be a merger of equals or would the merged association reinstate the traditional dominance of financial accountants over management accountants?

This Chapter explores these two macro pressures on the future of management accounting. First, I explore the relationship between financial and management accounting as professions. In many countries, each technology of practice is represented by separate professional associations. I explore the rationale for the creation of separate professional bodies and the trend towards consolidation of the profession. Second, I consider the relationship between financial accounting and management accounting as technologies of practice. I identify specific junctures at which management accounting and financial accounting diverged in the conceptualization of the stakeholders to whom they oriented their techniques and the decision-models that their information supports. Third, I examine the call for integrating financial and managerial accounting around a shared focus on shareholder value and risk, based on a common database. I conclude the Chapter by addressing the question of whether or not management accounting has a future as a distinct profession and technology of practice.

\section{Financial and Management Accounting as Professions}

The creation of associations of public accountants began in the UK in the late 1800s, spreading throughout the Commonwealth and internationally. The early associations were largely signalling devices to distinguish higher status public accountants from others. In time, the distinction between designated accountants versus those not affiliated with an association was argued to reflect the difference between "qualified" and "unqualified" accountants leading to the development of tests of competence and, ultimately, programs of training to justify this distinction (Hoskins and McVie, 1986; Anderson et al., 2005). These associations used both ascriptive and cognitive criteria to restrict access to credentials and, in general, succeeded in raising the economic and social status of their members.

The problem with this form of "exclusionary" closure is that it does not prevent others from forming their own associations and implementing a strategy of "usurpatory" closure, i.e. attempting to take privilege from those who had structured the profession (Parkin, 1982; Coronella et al., 2015). We thus see competing accounting associations in many countries and attempts by entrenched associations to limit the creation of new associations (or at least their intended domain of practice) through lawsuits, registration systems and unification proposals (Richardson, 1997; Walker and Shackelton, 1998).

Following WWI, accountants were increasingly employed in industry in part to provide information to produce financial statements for equity markets but also to manage control systems

in organizations that covered vast geographic distances (e.g. transportation companies), had extensive hierarchies (e.g. public sector organizations and large scale enterprises), or operated as conglomerates with many unrelated businesses where management accounting information replaced prices to guide the allocation of capital (Johnson, 1983; Chandler and Daems, 1979). Accountants in industry also were concerned about professional development and recognition. 
Eventually they started organizations to fulfil these functions which in some cases grew into designation granting associations.

Abbott (1988: 230) asserts that cost accounting "has been without question the most contested information jurisdiction in American history." This contest was mostly between accountants, engineers, economists and, more recently, information technologists. By the late 1920s, however, accountants had largely succeeded in claiming this domain in the UK and its colonies (although countries such as Germany, displayed a greater engineering influence over management accounting, see Armstrong, 1985; MacArthur, 2006) and it is in this period that management accounting associations arose. For example, the Institute of Cost and Works Accountants in the UK and the National Association of Cost Accountants in the US were formed in 1919 and the Society of Cost Accountants of Canada was launched in 1920.

Richardson (2002: 116) demonstrates that the independence of management accounting from financial accounting during these formative years was illusory

"...because of: (1) the use of financial accounting criteria to judge the quality of management accounting systems, (2) the assignment of management accountants to subordinate positions in organizational units whose primary purpose was financial accounting, (3) the dominance of financial accounting in the market for educational materials, (4) the judgment of the labor market that a financial accountant could replace a management accountant (but not vice versa), and (5) the need for a young profession to gain and retain the support of established interests in society".

There remained an implicit hierarchy among accountants long after management accountants began forming their own associations.

Given the status of management accountants as employees within organizations, these associations did not seek registration or licencing of all management accountants as is common with public accounting associations. In addition, since management accountants were not in direct competition with each other in the marketplace, these associations were less concerned with closure. In fact, management accounting associations sought to expand their scope of practice and their membership. These associations, for example, became involved in the scientific management movement and in Canada expanded their title to include industrial engineers, a term used for efficiency experts (i.e. their name was changed in 1930 from the Society of Cost Accountants of Canada to the Society of Cost Accountants and Industrial Engineers; see also Latzer, 1955). More recently, management accounting associations redefined their members as business consultants and strategic decision-makers rather than just cost or management accountants (e.g. Russel et al., 1999; Richardson and Jones, 2007; Suddaby and Viale, 2011). This trend towards a strategic focus was supported by the rise of personal computing and enterprise resource systems that made accounting information readily available to managers throughout the organization; turning management accountants into coaches to ensure appropriate use of this information rather than simply information providers (Granlund and Malmi, 2002).

The creation of management accounting associations across nations is not uniform. Based on the list of professional associations in IFAC I identified 186 professional accounting associations (as 
of 2015). On average there were 1.65 associations in each country; code law countries averaged 1.46 professional associations while common law countries averaged 2.08 professional associations $(\mathrm{t}=1.88, \mathrm{p}<0.05)$. Typically, if only one association existed it tended to be an association of auditors. Where multiple associations existed, often there were competing associations of public accountants but usually only one management accounting association in each country.

These statistics suggest that management accounting as a distinct profession is a culturally specific phenomenon. It is related to the Anglo-Saxon, common-law heritage of the profession and the rise of industrial economies. Within those contexts, management accounting succeeded in competition with other management information providers because of its connection to the production of financial statements for equity markets; where this information was not crucial (e.g. bank-based capitalist systems and systems based on relationships, Rajan and Zingales, 1998), engineers and economists tended to be more successful in claiming this domain. Further international research is needed to understand these differences and the processes that generate them. The first section of this book contributes to our understanding of local variations in management accounting practice in a range of countries.

Throughout history there has been a trend towards consolidation of the accounting profession through voluntary mergers and statutory registration processes. Although these merger activities typically focus on bringing together public accountants both to facilitate regulation by the state and to provide market power to practitioners (Richardson and Kilfoyle, 2012), often the goal is to consolidate the entire profession - bringing management accountants and financial accountants together in one organization - or at least, to register all accountants as a way of preventing the entry of "unqualified" public accountants from cognate areas of practice into the audit market. The issue underlying the process is one of professional "drift" where members of one association, nominally focussed on one aspect of accounting, shift their occupational roles into related areas (e.g. a person trained as an auditor becomes the controller of a former client) without changing their professional affiliation. As will be discussed below, there may also be a "cognitive drift" where the technical domain of one profession encroaches on that of another profession (Walker, 2004; Suddaby et al., 2015). Over time these professional and cognitive drifts undermined the distinctions between accounting associations resulting in duplication of professional development services and conflict over professional boundaries.

The process of professional drift of accountants is, in part, an unintended consequence of the structure of public accounting firms (Greenwood and Empson, 2003). These firms historically employed a steep hierarchical structure with relatively few partners compared with the number of accountants who train in the firm and provide the labour on which audits were based (the rise of digital records and statistical auditing has changed the need for this level of skilled labour). After junior accountants achieved their designation they had to fight for these limited partner positions or make the transition into industry. The profession thus tended to over-produce financial accountants to meet the entry level skill needs of the public accounting firms and this over supply of labour migrated into cognate fields with a public accounting designation where they would 
compete with accountants who held a management accounting designation. This competition in the labour market encouraged merger talks within the profession.

The initial wave of profession formation in accounting occurred within national boundaries but always mindful of the implications of events in one country for the aspirations of associations in other countries (Poullaos and Sian, 2010; Chua and Pollaos, 2010; Parker, 2005). This transformed into a concern with mutual recognition of credentials and licences across national borders to simplify migration of skilled labour and the flows of capital (Peek et al., 2007²). Concern with these issues was amplified after the negotiation of the General Agreement on Trade in Services within the World Trade Organization during the Uruguay Round of negotiations (1986-1994) (Arnold, 2005). A natural projection of this trend is the proposed creation of transnational credentials such as the failed XYZ credential (Shafer and Gendron, 2004) or the more recent Certified Global Management Accountant (CGMA) designation offered as a joint venture of the AICPA and CIMA. Alternatively, the opening of trade in services between nations may encourage individual professional associations to seek to globalize their credentials. The UKs ACCA is currently implementing this strategy with aggressive recruitment campaigns in various countries. The aspirations of these global players was one of the motivations for the merger of financial and management accounting associations in Canada to create a professional association with sufficient scale to compete in an international credential environment (see Chapter X).

A dilemma facing the profession is that a "unified" profession, i.e. where all accountants use a single designation, does not change the fact that accountants perform a diverse set of tasks and require differentiated professional development opportunities and guidance. The US AICPA for many years resisted the creation of post-designation specialties arguing that they would be divisive to the profession but after twenty years of debate finally allowed specialty designations (Chiasson et al., 2006). This tension between the desire for a single professional identity while allowing diversity in practice has been faced by medicine and law (among other professions) (Richardson, 1987; Richardson and Jones, 2007). At issue is the form of segmentation within the profession and how those segments will be related to each other.

This thumbnail history of the accounting profession shows that management accounting was organized as a profession late in the process of separating accounting from other professional fields. The management accounting profession was initially defined as much by what it was not than what it was - i.e. it referred to accountants who were not in public practice - but beyond this it included tax, internal control, internal audit, performance measurement, management control etc. The motivation to consolidate financial and management accounting professional associations appears to be driven by three factors:

1. Management accounting associations provided an organizational basis from which practitioners could attempt usurpatory closure in response to the exclusionary closure of public/financial accounting associations. Consolidation of the profession represents a new boundary for exclusionary practices while reducing the risk of usurpatory closure.

\footnotetext{
${ }^{2}$ This is an under-researched and theorized aspect of the professional organizations literature, but see Iredale (2001).
} 
2. Financial accounting associations over-produced audit trained practitioners to meet the labour needs of public accounting firms but these "excess" practitioners migrated into management accounting roles pushing their audit/financial accounting professional body to provide services beyond their original mandate. I refer to this as a process of "professional drift". This process undermined the differentiation of financial versus managerial accounting associations and created inefficient duplication of services.

3. The creation of international trade in services has created the demand for transnational professional associations. To the extent that scale of professional associations is necessary for competition and nationalism is still a motivation behind professional association formation, financial and management accounting associations may merge to compete against other international associations entering their domestic market.

\section{Financial and Management Accounting as Technologies}

The relationship between financial and managerial accounting as technologies is complex. On the one hand, management accounting systems provide the cost data and inventory valuations that are used to support financial reporting and, in this sense, are subordinate to financial reporting (Richardson, 2002). There is no question that management accountants and financial accountants share a common knowledge base at a basic level (Richardson, 1992). On the other hand, management accountants have been urged to act as internal consultants within organizations focusing on strategic initiatives and performance measurement/management rather than routine costing processes (Russell et al., 1999). There is also a well-recognized tension between the information needed for stewardship versus investment decision-making (Beyer et al., 2010). Management accounting focuses on the stewardship or implementation aspects of management actions while financial accounting focuses on the investment uses of information. Management accounting is thus simultaneously a profession that supports financial reporting while attempting to develop beyond this narrow scope.

Complicating this relationship is the idea that financial reporting should provide stakeholders with insight into the metrics that managers use to run the business. This can be taken to imply that managers should and do manage by the numbers (Geneen, 1984; Papadakis et al., 1998) but some have suggested that financial statements are "too late, too aggregated and too distorted" (Johnson and Kaplan, 1991) to be used to run organizations. Even so, there is pressure for management accounting systems to become isomorphic with the needs of financial reporting (Johnson, 1991; Weißenberger and Angelkort, 2011). The key question is thus whether or not management accounting and financial accounting represent two distinct technologies of practice or are they converging on a single information set that can support managerial decision-making and investor decision-making. I identify two historical junctures at which management accounting has diverged from the information needs of financial reporting and then return to consider the current state of this relationship.

The discussion that follows is biased towards developed economies. The link between management accounting technologies and the institutional context within which it is practiced is 
still developing (Hopper et al., 2009). The assumptions underlying the discussion below are that management accounting and financial accounting technologies reflect the separation of ownership and control, i.e. they have different primary stakeholders, but that both are evolving within a "rationalized" industrial society. This implies that individuals are using accounting technologies to make decisions that advance their individual interests and to improve the efficiency of resource use. The primacy of this institutional logic as a determinant of organizational structure and practice is subject to considerable debate. Where ownership and control are not separate, or where the ostensible goal of management is not the efficient allocation and use of resources, then the observations below may not reflect local management accounting practice.

The first major break in the relationship between financial and management accounting as technologies was the "marginal cost" revolution notably championed by Horngren both in his academic work (e.g. Horngren and Sorter, 1961; Sorter and Horngren, 1962; Horngren, 1995) and his textbooks (e.g. Horngren, 1962). The concept of marginal cost has a long history in economics dating to the late 1800s but received significant impetus after WWII with the refinement of game theory and expected value analysis. Prior to Horngren's work, Clark (1923) made the point that overhead costs were usually fixed and therefore irrelevant to most managerial decisions: only opportunity costs are relevant. Horngren's contribution was to apply these concepts to accounting practice differentiating the "full cost" information used in financial reporting from the opportunity cost information used in managerial decision-making.

Horngren intended to realign cost accounting to fit the decision needs of managers, essentially "inventing" management accounting as a discipline.

"This book's goal is to put cost accounting in focus as a highly developed quantitative device for helping managers select and reach their objectives. Ample attention is devoted to accounting systems and procedures for data accumulation, but stress is given to the concepts that make modern cost accounting dynamic and vital. In short, the major theme of the book is "different costs for different purposes.' (Horngren 1962, vii)

The decision-making focus of management accounting meant that not all costs were relevant to every decision and some cost concepts, such as opportunity cost, relied on information outside the accounting system itself.

This change in focus meant that management accounting systems no longer integrated with the financial accounting system (Richardson, 2002). They might contain information that would not be considered "auditable" either because it was not based on transaction data or it was future oriented information specific to particular decisions (e.g. projections etc.) (cf. Joseph, et al., 1996). Two related areas of practice that have not been fully integrated into management accounting are cost analysis and estimation, and cost-benefit analysis. The cost estimation domain is still dominated by engineers and non-accountants and largely based on learning curves and historical cost information (e.g. parametric costing). Cost/benefit analysis, on the other hand, is dominated by economists and is more common in the public sector where the objective function under which managers' work, is more complex and subjective than the profit maximization models used in business settings. These domains include technologies of practice that would allow management accounting to further expand away from financial reporting. 
A related development was the introduction of standard costing and variance analysis. Standard costing substitutes a "norm" for what a cost "should" be in place of actual costs. The choice of a standard-cost might be informed by knowledge of planned changes in technology and learning curves. The use of standard costs simplifies accounting in long-chain production processes and highlights variations from expectations that facilitates management-by-exception (Brownell, 1983). After WWII, standard costing and variance analysis were common components of cost accounting courses. These techniques establish a baseline for performance evaluation and managerial decision-making that is distinct from the transaction-based records underlying financial reporting.

The second break in the relationship between financial accounting and management accounting as technologies was the strategic revolution (Bromwich, 1990; Langfield-Smith, 1997). Johnson and Kaplan (1991) goaded management accountants into renewing the relevance of their technique to management decision-making. This work focused attention on the role of management accounting in implementing strategy and providing the incentive systems that guide strategic behaviour (MacDonald and Richardson, 2002). A key technical development was the balanced scorecard and strategy maps (Kaplan and Norton, 1996, 2001, 2004).

At the same time there was a change in the focus of financial accounting that reinforced the divergence of perspectives. Initially financial reports were intended as "general purpose" documents for multiple stakeholders. As formal standard-setting processes were put in place to guide the development of financial reports however it was found to be impossible to produce general purpose reports that were internally consistent. The search for a conceptual framework for financial reporting led standard-setters to focus on equity valuation models, "value relevance" (Barth et al., 2001; Holthausen and Watts, 2001) and equity market reactions to new accounting standards as a test of their relevance (Hines, 1989; Young, 2006). Management, however, must be mindful of multiple stakeholders and management accountants provide data to support this broader perspective on the long run success of organizations (Ratnatunga, et al., 2015). The increasingly distinct sets of stakeholders that are the focus of financial reporting and management accounting, respectively, encourages a divergence of practice in each area (cf. Ball, 2004).

The Institute of Management Accountants (2008) in the US has adopted the strategic perspective, stating:

"Management accounting is a profession that involves partnering in management decision making, devising planning and performance management systems, and providing expertise in financial reporting and control to assist management in the formulation and implementation of an organization's strategy"

The sketch of the development of management accounting as a technology of practice suggests that management accounting is distinct from financial accounting in:

1. Focusing on opportunity costs to support management decision-making and encouraging different information for different decisions within the same firm;

2. Providing information relevant to a wide group of stakeholders rather than being focused on information relevant to the decision-model of shareholders; 
3. Varying management accounting practice according to the strategy of the organization particularly in the choice of performance measures to drive strategy implementation and the construction of information specific to the decision-needs of local managers.

\section{Integrating Financial Reporting and Management Accounting}

The call for a single system of accounting for both managerial decision-making and stakeholder reporting has deep roots. It is based on three considerations. First, in equity-focused economies, the claim is made that managers should always act in the best interests of shareholders, i.e. their decisions should focus on maximizing shareholder value. Financial statements provide a means by which shareholders monitor management and are often used to build compensations systems intended to align management interests with those of shareholders. But more than this, it is argued that shareholders should be able to see the information on which managers make their decisions in order to differentiate between good/poor outcomes and good/poor decisions, i.e. to separate skill from luck. This suggests that the information system used by management should be a more detailed and real time version of the information provided to shareholders and not an information system based on a different logic of practice (cf. Berliner \& Brimson, 1988; Bhimani, 2009; Hemmer and Labro, 2008). This logic also challenges financial accounting standard setters to move away from "arbitrary" standards and to adopt those that have proven to be "value relevant". So if financial statements are built on information that drives shareholder value and managerial compensation and performance evaluation is contingent on financial statement outcomes, why would managers use a different set of information in decision-making?

A related trend in both management and financial accounting is a focus on risk (Power, 2004; Hayne and Free, 2014). The concept of risk draws attention to possible future outcomes and contingencies for the organization and whether or not the organization can withstand shocks (business resiliency), react constructively to challenges (contingency planning), and innovate to meet new challenges (innovativeness). The financial statements with their traditional backward perspective have been inadequate to provide insights into this aspect of corporate performance. Recent experiments in corporate reporting such as sustainability reporting (and related reports on corporate social responsibility, environmental and social impact, and intellectual capital) begin to provide more useful data on these dimensions but, in this case, the assumption is that management is developing information systems to support business resilience and investors would find disclosure of this information value relevant.

This argument for integration suggests that the merger of management accounting and financial accounting as technologies of practice is most likely in publicly listed companies operating within strong shareholder rights jurisdictions.

Second, the development of information technologies that allow real time data capture and report creation has been suggested to remove the need for separate systems for managerial decisionmaking. Johnson and Kaplan (1987: 193) suggested that financial reports were "too aggregate, too distorted and too late" to be useful for managerial decision-making. This critique, in part, suggests the conditions under which financial reporting could be used for management decision-making, 
i.e. if it was available in disaggregate form, made theoretically sound distinctions between cost categories and use theoretically appropriate allocation methods (including not allocating true joint costs), and was available in real time. Hopper et al. (1992) report a pilot study in which they examined whether or not financial accounting systems dominated management accounting systems. They found that among their small sample both financial accounting and management accounting relied on the same database but processed and formatted the information in distinct ways. While this suggests a level of integration around "primitive" accounting data, both systems can maintain their independence. However, if the underlying "primitive" system is based on the ontology of financial accounting (i.e. limited to transaction-based, auditable information), it remains unclear if the potential of management accounting information could be realized. The existence of "vernacular accounting systems" alongside the formal accounting systems of organizations suggests that this form of integration may not entirely meet the information needs of managers (Kilfoyle et al., 2013).

Finally, the move to market-based information under IFRS weakens the requirement that financial statements be based on transaction data and opens up the possibility that the "opportunity cost" information recommended for managerial decision-making could be consistent with the information reported in financial statements (Taipaleenmäki \& Ikäheimo, 2013; Ahmed \& Duellman, 2013). As Ball (2006) notes, however, the "fair value" provisions of IFRS are among the most controversial aspects of global standards and are an area where significant domestic variation in application will occur.

Weißenberger and Angelkort (2011) use the transition of management accounting systems in Germany from stand-alone to integrated management accounting/financial accounting systems to explore the potential benefit of integration. They do not find a direct technical benefit from the change but do report a positive relationship between the change and the effectiveness of the controllership function within the firm based on the creation of single "language" for talking about both investor issues and management issues. Although not tested, presumably a similar benefit would have been found if the financial reporting system moved to the management accounting conceptual foundation. Typically, however, integration is taken to imply the abandonment of a distinct management accounting system in favour of the compliance-based financial accounting system. The hegemony of financial reporting remains powerful.

\section{Conclusion}

Management accounting as a distinct profession and body of knowledge is a relatively recent addition to and differentiation of the accounting profession as a whole. It is a creation largely of Anglo-Saxon countries and distinct management accounting associations outside this context are less common. The existence of distinct associations of management accountants is threatened by professional drift (associations following the movement of their members into related fields) and cognitive drift (increasing overlap of the knowledge base of professions in cognate jurisdictions) which generates competition and conflict between professional associations. The trend is to resolve these issues through the consolidation of the profession. 
Management accounting as a technology of practice focuses on the decision needs of managers and on supporting managers as they implement strategy and manage a diverse stakeholder population. There are calls for greater convergence of financial and managerial information technologies. While there are significant reasons to maintain the distinction between management and financial accounting, the continuing hegemony of financial reporting and audit-focused professional associations within the profession means that these calls must be taken seriously. All of this raises the question: is there an independent future for management accounting as a technology and profession?

To the extent that management accounting has become a technology of practice that extends beyond investment-focused information and seeks to anticipate changes in the information needs of diverse stakeholders, there remain incentives to develop this technology. The challenge will be whether the convergence of financial and managerial accounting as professions allows them to continue diverging as technologies of practice. 


\section{References}

Ahmed, A. S., \& Duellman, S. (2013). Managerial overconfidence and accounting conservatism. Journal of Accounting Research, 51(1), 1-30.

Anderson, M., Edwards, J. R., \& Chandler, R. A. (2005). Constructing the 'well qualified' Chartered Accountant in England and Wales. The Accounting historians Journal, 5-54.

Armstrong, P. (1985). Changing management control strategies: the role of competition between accountancy and other organisational professions. Accounting, Organizations and Society, 10(2), 129-148.

Arnold, P. J. (2005). Disciplining domestic regulation: the World Trade Organization and the market for professional services. Accounting, Organizations and Society, 30(4), 299-330.

Ball, R. (2004) Corporate Governance and Financial Reporting at Daimler-Benz (DaimlerChrysler) AG: From "Stakeholder" toward a "Shareholder Value" Model. In Hopwood, A., Leuz, C. and Pfaff, D. (eds.) The Economics and Politics of Accounting: International Perspectives on Research, Trends, Policy, and Practice, Oxford University Press.

Ball, R. (2006). International Financial Reporting Standards (IFRS): pros and cons for investors. Accounting and business research, 36(sup1), 5-27.

Barth, M. E., Beaver, W. H., \& Landsman, W. R. (2001). The relevance of the value relevance literature for financial accounting standard setting: another view. Journal of accounting and economics, 31(1), 77-104.

Berliner, C., \& Brimson, J. A. (Eds.). (1988). Cost management for today's advanced manufacturing: The CAM-I conceptual design. Harvard Business School Press.

Beyer, A., Cohen, D. A., Lys, T. Z., \& Walther, B. R. (2010). The financial reporting environment: Review of the recent literature. Journal of accounting and economics, 50(2), 296-343.

Bhimani, A. (2009). Risk management, corporate governance and management accounting: Emerging interdependencies. Management Accounting Research, 20(1), 2-5.

Boyns, T., \& Edwards, J. R. (1997). The Construction of Cost Accounting Systems in Britain to 1900: The Case of the Coal, Iron and Steel Industries 1. Business History, 39(3), 1-29.

Boyns, T., \& Edwards, J. R. (2006). The development of cost and management accounting in Britain. Handbooks of Management Accounting Research, 2, 969-1034.

Bromwich, M. (1990). The case for strategic management accounting: the role of accounting information for strategy in competitive markets. Accounting, Organizations and Society, 15(1-2), 27-46.

Brownell, P. (1983). The motivational impact of management-by-exception in a budgetary context. Journal of Accounting Research, 456-472. 
Chandler, A.D. and Daems, H., (1979) Administrative coordination, allocation and monitoring: A comparative analysis of the emergence of accounting and organization in the USA and Europe. Accounting, Organizations and Society, 4(1): 3-20.

Chiasson, M., Gaharan, C., \& Mauldin, S. (2006). A History of the Development of the AICPA's Specialty Designation Program. The CPA Journal, 76(1), 64.

Chua, W. F., \& Poullaos, C. (2002). The Empire Strikes Back? An exploration of centre-periphery interaction between the ICAEW and accounting associations in the self-governing colonies of Australia, Canada and South Africa, 1880-1907. Accounting, Organizations and Society, 27(4), 409-445.

Clark, J. M. (1923). The Economics of Overhead Costs. The Journal of Political Economy, 31(5), 606-36.

Coronella, S., Sargiacomo, M., \& Walker, S. P. (2015). Unification and Dual Closure in the Italian Accountancy Profession, 1861-1906. European Accounting Review, 24(1), 167-197.

Geneen, H. S. (1984). The case for managing by the numbers. Fortune, 110(7), 78-81.

Granlund, M., \& Malmi, T. (2002). Moderate impact of ERPS on management accounting: a lag or permanent outcome?. Management accounting research, 13(3), 299-321.

Greenwood, R., \& Empson, L. (2003). The professional partnership: relic or exemplary form of governance?. Organization Studies, 24(6), 909-933.

Hemmer, T., \& Labro, E. (2008). On the optimal relation between the properties of managerial and financial reporting systems. Journal of Accounting Research, 46(5), 1209-1240.

Hayne, C., \& Free, C. (2014). Hybridized professional groups and institutional work: COSO and the rise of enterprise risk management. Accounting, Organizations and Society, 39(5), 309330.

Hines, R. D. (1989). Financial accounting knowledge, conceptual framework projects and the social construction of the accounting profession. Accounting, Auditing \& Accountability Journal, 2(2): 72-91.

Holthausen, R. W., \& Watts, R. L. (2001). The relevance of the value-relevance literature for financial accounting standard setting. Journal of accounting and economics, 31(1), 3-75.

Hopper, T., Kirkham, L., Scapens, R. W., \& Turley, S. (1992). Does financial accounting dominate management accounting - a research note. Management Accounting Research, 3(4), 307311.

Hopper, T., Tsamenyi, M., Uddin, S., \& Wickramasinghe, D. (2009). Management accounting in less developed countries: what is known and needs knowing. Accounting, Auditing \& Accountability Journal, 22(3), 469-514.

Horngren, C. T., \& Sorter, G. H. (1961). "Direct" Costing for External Reporting. The Accounting Review, 36(1), 84-93. 
Horngren, C. T. (1995). Management accounting: this century and beyond. Management Accounting Research, 6(3), 281-286.

Hoskin, K.W. and Macve, R.H. (1986), "Accounting and the examination: a genealogy of disciplinary power", Accounting, Organizations and Society, Vol. 11 No. 2, pp. 105-36.

Institute of Management Accountants [IMA]. (2008). Definition of management accounting. http://www.imanet.org/docs/default-source/research/sma/definition-of-mangementaccounting.pdf?sfvrsn=2 (August, 2016)

Iredale, R. (2001). The migration of professionals: theories and typologies. International Migration, 39(5), 7-26.

Johnson, H. T. (1983). The search for gain in markets and firms: a review of the historical emergence of management accounting systems. Accounting, Organizations and Society, 8(2), 139-146.

Johnson, H. T., \& Kaplan, R. S. (1991). Relevance lost: the rise and fall of management accounting. Harvard Business Press.

Johnson, H. T. (1991). Managing by remote control: recent management accounting practice in historical perspective. In Temin, P. (Ed.) Inside the business enterprise: Historical perspectives on the use of information (pp. 41-70). University of Chicago Press.

Joseph, N., S. Turley, J. Burns, L. Lewis, R. Scapens and A. Southworth (1996) External Financial reporting and management information: a survey of UK management accountants. Management Accounting Research, 7(1), 73-93.

Kaplan, R. S., \& Norton, D. P. (1996). The balanced scorecard: translating strategy into action. Harvard Business Press.

Kaplan, R. S., \& Norton, D. P. (2001). The strategy-focused organization: How balanced scorecard companies thrive in the new business environment. Harvard Business Press.

Kaplan, R. S., \& Norton, D. P. (2004). Strategy maps: Converting intangible assets into tangible outcomes. Harvard Business Press.

Kilfoyle, E., Richardson, A. J., \& MacDonald, L. D. (2013). Vernacular accountings: Bridging the cognitive and the social in the analysis of employee-generated accounting systems. Accounting, Organizations and Society, 38(5), 382-396.

Langfield-Smith, K. (1997). Management control systems and strategy: a critical review. Accounting, Organizations and Society, 22(2), 207-232.

Latzer, P. J. (1955). Cost Accountant and Industrial Engineer. The Accounting Review, 348-350.

Loft, A. (1986). Towards a critical understanding of accounting: the case of cost accounting in the UK, 1914-1925. Accounting, Organizations and Society, 11(2), 137-169.

MacArthur, J. B. (2006). Cultural Influences on German versus US Management Accounting Practices. Management Accounting Quarterly, 7(2): 10-12 
MacDonald, L. D., \& Richardson, A. J. (2002). Alternative perspectives on the development of American management accounting: relevance lost induces a renaissance. Journal of Accounting Literature, 21, 120.

Papadakis, V. M., Lioukas, S., \& Chambers, D. (1998). Strategic decision-making processes: the role of management and context. Strategic management journal, 19(2), 115-147.

Parkin, F. (1982). Social closure and class formation. In Giddens, A. and Held, D. (Eds.) Classes, power, and conflict (pp. 175-184). Macmillan Education UK.

Peek, L., Roxas, M., Peek, G., McGraw, E., Robichaud, Y., \& Villarreal, J. C. (2007). NAFTA professional mutual recognition agreements: comparative analysis of accountancy certification and licensure. Global Perspectives on Accounting Education, 4: 1-27

Poullaos, C., \& Sian, S. (Eds.). (2010). Accountancy and empire: The British legacy of professional organization. Routledge.

Power, M. (2004). The Risk Management of Everything: Rethinking the Politics of Uncertainty London: Demos.

Parker, R. H. (2005). Naming and branding: accountants and accountancy bodies in the British Empire and Commonwealth, 1853-2003. Accounting History, 10(1), 7-46.

Rajan, R. G., \& Zingales, L. (1998). Which capitalism? Lessons form the east Asian crisis. Journal of Applied Corporate Finance, 11(3), 40-48.

Ratnatunga, J., Michael, S. C., \& Wahyuni, D. (2015). Societal Role Expectations of Management Accounting Professionals: An Australian Study. Advances in Management Accounting (pp. 29-48.

Richardson, A. J. (1987). Professionalization and intraprofessional competition in the Canadian accounting profession. Work and Occupations, 14(4), 591-615.

Richardson, A.J. (1992) "Accounting Competence: Canadian Experiences" in Anyane-Ntow, K. (Ed.) International Handbook of Accounting Education and Certification Oxford: Pergamon pp. 263-278

Richardson, A. J. (1997). Social closure in dynamic markets: the incomplete professional project in accountancy. Critical Perspectives on Accounting, 8(6), 635-653.

Richardson, A. J. (2002). Professional dominance: the relationship between financial accounting and managerial accounting, 1926-1986. The Accounting Historians Journal, 91-121.

Richardson, A. J., \& Jones, D. B. (2007). Professional "brand”, personal identity and resistance to change in the Canadian accounting profession a comparative history of two accounting association merger negotiations. Accounting History, 12(2), 135-164.

Richardson, A. J., \& Kilfoyle, E. (2012). Merging the Profession: A Historical Perspective on Accounting Association Mergers in Canada. Accounting Perspectives, 11(2), 77-109. 
Russell, K. A., Siegel, G. H., \& Kulesza, C. S. (1999). Counting more, counting less. Strategic Finance, 81(3), 38.

Shafer, W. E., \& Gendron, Y. (2005). Analysis of a failed jurisdictional claim: The rhetoric and politics surrounding the AICPA global credential project. Accounting, Auditing \& Accountability Journal, 18(4), 453-491.

Sorter, G. H., \& Horngren, C. T. (1962). Asset Recognition and Economic Attributes--The Relevant Costing Approach. The Accounting Review, 37(3), 391-399.

Suddaby, R., Saxton, G. D., \& Gunz, S. (2015). Twittering change: The institutional work of domain change in accounting expertise. Accounting, Organizations and Society, 45, 52-68.

Suddaby, R., \& Viale, T. (2011). Professionals and field-level change: Institutional work and the professional project. Current Sociology, 59(4), 423-442.

Taipaleenmäki, J., \& Ikäheimo, S. (2013). On the convergence of management accounting and financial accounting-the role of information technology in accounting change. International Journal of Accounting Information Systems, 14(4), 321-348.

Walker, S. P. (2004). Conflict, collaboration, fuzzy jurisdictions and partial settlements. Accountants, lawyers and insolvency practice during the late 19th century. Accounting and Business Research, 34(3), 247-265.

Walker, S. P., \& Shackleton, K. (1998). A ring fence for the profession: advancing the closure of British accountancy 1957-1970. Accounting, Auditing \& Accountability Journal, 11(1), 3471.

Weaver, S. C., \& Whitney, D. (2015). The global growth of the CMA: IMA's highly respected certification is becoming more in demand by professionals around the world. Strategic Finance, 96(11), 26-29.

Weißenberger, B. E., \& Angelkort, H. (2011). Integration of financial and management accounting systems: The mediating influence of a consistent financial language on controllership effectiveness. Management Accounting Research, 22(3), 160-180.

Young, J. J. (2006). Making up users. Accounting, Organizations and Society, 31(6), 579-600. 